prof. dr hab. inż. Janusz Mielniczuk

Politechnika Poznańska

Instytut Pojazdów Szynowych „,TABOR”

mgr inz. Pawel Kuligowski

Instytut Pojazdów Szynowych „,TABOR”

\title{
Analiza wytrzymałości konstrukcji wagonu osobowego z zastosowaniem materiału porowatego (1)
}

\begin{abstract}
$W$ artykule zaprezentowano konstrukcję nośnq wagonu osobowego, w której do jego budowy wykorzystano elementy powierzchniowe o strukturze porowatej. Przedstawiono rezultaty analiz wytrzymatości dla różnych rozwiazań konstrukcyjnych wagonu oraz porównano z wynikami uzyskanymi dla klasycznej budowy wagonu. Artykut składa się z dwóch części. W pierwszej części (1) omówiono możliwości zastapienia klasycznej konstrukcji szkieletowej dachu elementami powierzchniowymi o strukturze porowatej.

Praca powstała w ramach projektu badawczego nr N509 014 32/0995 finansowanego przez Ministerstwo Nauki i Szkolnictwa Wyższego ze środków na naukę w latach 2007־2008.
\end{abstract}

\section{Wprowadzenie}

Praca stanowi kontynuację wcześniej podjętych i opublikowanych badań [1,2 i 3]. Tematyką ich są rozważania dotyczące możliwości zastosowania porowatych materiałów konstrukcyjnych w budowie wagonów osobowych.

W [2 i 3] przedstawiono rezultaty analiz wytrzymałości fragmentu konstrukcji dachu wagonu pasażerskiego wykonanego z elementów powierzchniowych o strukturze porowatej.

W [2] klasyczną jednorodną stalową blachę poszyciową zastapiono powłoką o strukturze porowatej, przy czym szkielet konstrukcji dachu pozostawiono $\mathrm{w}$ dotychczasowej postaci. Z przeprowadzonej analizy wynika, że w celu zachowania odpowiedniej sztywności rozpatrywanego fragmentu dachu, grubość powłoki porowatej musi wzrosnąć w zależności od porowatości nawet o $60 \% \mathrm{w}$ stosunku do powłoki klasycznej, ale mimo to jej masa nie przekroczy $60 \%$ masy dotychczasowego rozwiązania.

W [3] omówiono wyniki analizy fragmentu dachu, w którym zamiast konstrukcji szkieletowej wprowadzono porowatą powłokę walcową o odpowiednio większej grubości, wykonaną ze spienionego aluminium. Wynika z niej, że w celu zagwarantowania porównywalnej sztywności przy działaniu obciążeń zewnętrznych, zwłaszcza masy śniegu, nie można zrezygnować całkowicie ze szkieletu stalowego.

Ze względu na fakt, że konstrukcja dachu stanowi ważny element składowy sztywności całego pudła wagonu, na podstawie analizy wydzielonej części konstrukcji dachu trudno jednoznacznie określić, w jakiej postaci należy zachować szkielet.

Biorąc powyższe pod uwagę, analizie wytrzymałości poddano całą konstrukcję nośną pudła wagonu.
Dla celów porównawczych rozpatrzono zachowanie dotychczasowego rozwiązania szkieletowego dachu oraz z porowata powłoką walcową, wprowadzoną w konstrukcję dachu między drzwiami wejściowymi do wagonu.

\section{Obciążenia, modele obliczeniowe i omówienie wyników analiz}

Konstrukcję wagonu poddano podstawowym obciążeniom wymaganym w przepisach ustalonych przez międzynarodowe organizacje kolejowe (UIC, ERRI) oraz w normach europejskich. Należą do nich przede wszystkim obciążenia pionowe pochodzące od masy własnej oraz pasażerów, a także obciążenia wzdłużne wynikające ze ściskania wagonu w osi zderzaków i sprzęgu oraz rozciagania w osi sprzęgu. Bardzo ważnym obciążeniem dla konstrukcji dachu jest masa zalegającego na nim śniegu.

Obliczenia wytrzymałości konstrukcji pudła wagonu konieczne do przeprowadzenia analiz wykonano metodą elementów skończonych (MES) przy pomocy systemu obliczeniowego ABAQUS. Wykorzystując istniejącą w rzeczywistości symetrię konstrukcji pudła rozpatrzono model obejmujacy tylko ćwiartkę wagonu, który przedstawiono na rys.1. Do modelowania zastosowano przede wszystkim element powłokowy S8R, przy czym dla konstrukcji szkieletowej przyjęto jednorodny przekrój powłokowy a dla powłoki walcowej wielowarstwowy (złożony) przekrój powłokowy.

Własności materiałowe powłoki, zmienne na grubości przekroju poprzecznego, zostały zamodelowane w identyczny sposób jak w [2] za pomocą szeregu 
warstw o stałej grubości oraz o stałych wskaźnikach mechanicznych. Zmianę własności mechanicznych na poszczególnych warstwach omówiono w [2].

Badanie wykonano dla następujących danych materiałowych: elementy szkieletu i klasyczne poszycie jak dla stali $\left(E=2,05 \cdot 10^{5} \mathrm{MPa}, \nu=0,3\right)$, a porowata powłoka walcowa o współczynniku porowatości $\mathrm{e}_{0}=0,9$ jak dla aluminium $\left(\mathrm{E}_{1}=0,7 \cdot 10^{5} \mathrm{MPa}, v=0,3\right)$.

Przyjęto następujące obciążenia: ściskające $2,0 \mathrm{MN}$, rozciagające $1,5 \mathrm{MN}$, masa własna pudła około 41 t, masa pasażerów około 4,6t oraz obciążenie śniegiem około $2 \mathrm{kN} / \mathrm{m}^{2}$.

$\mathrm{Z}$ wstępnych obliczeń przeprowadzonych dla modelu pudła $\mathrm{z}$ dachem o konstrukcji szkieletowej oraz $\mathrm{Z}$ dachem tylko z porowatej powłoki walcowej o grubości $11 \mathrm{~mm}$, wprowadzonej między drzwiami ścian bocznych wynika, że obciążenia wzdłużne w obu rozwiązaniach konstrukcyjnych wywołują bardzo zbliżone stany odkształceń i naprężeń. Zupełnie inaczej sytuacja przedstawia się $\mathrm{w}$ przypadku obciążenia pionowego. Znaczne odkształcenia $w$ strefie połączenia dachu ze ścianą boczną w środku długości wagonu powodują że ugięcie ostoi pozostaje na podobnym poziomie (około 9,4mm) ale zmniejszenie odległości między dachem a ostoją $\mathrm{w}$ środku wagonu jest ponad czterokrotnie większe niż w konstrukcji klasycznej, a wzrost szerokości pudła na wysokości pasa dachowego jest prawie trzykrotny. W przypadku obciążenia śniegiem zmiana przedstawionych powyżej wielkości jest jeszcze większa i przekracza kilkadziesiąt razy. Opisana sytuacja spowodowana jest brakiem jakiegokolwiek elementu o znacznej sztywności, wiążącego pasy dachowe w środku długości wagonu. Potwierdzają to wcześniej uzyskane rezultaty dla fragmentu konstrukcji dachu.

Wobec powyższego zdecydowano wprowadzić $\mathrm{w}$ środku wagonu dwie symetrycznie położone krokwie stanowiące przedłużenie słupków ścian bocznych oraz połączyć je ściagami. Nowe elementy wykonano $\mathrm{z}$ otwartych profili stalowych o grubości $4 \mathrm{~mm}$.

Wstępne analizy przeprowadzone dla takiego rozwiązania potwierdzają słuszność jego zastosowania. W przypadku obciazżenia pionowego otrzymane wyniki są praktycznie zgodne z rezultatami dla konstrukcji klasycznej. Natomiast dla obciążenia śniegiem odkształcenia przekroju środkowego pudła wagonu są znacznie mniejsze niż dla samej powłoki walcowej i w około $30 \%$ odbiegają od konstrukcji klasycznej. Maksymalne odkształcenia powłoki pojawiają się natomiast $\mathrm{w} 1 / 4$ długości wagonu a więc w połowie odległości między podparciami na krokwiach. Są one jednak znacznie mniejsze niż w przypadku samej powłoki walcowej.
Ze względu na fakt, że przepisy kolejowe nie określają ściśle kryteriów dla obciążenia śniegiem, trudno precyzyjnie określić dopuszczalne odkształcenia dachu. Wzorując się na kryterium określonym dla przypadku obciążenia masą pracownika obsługi a mianowicie brak odkształceń trwałych można przyjąć, że odkształcenia, które wywołuja poziom naprężeń w analizowanej konstrukcji znacznie niższy niż granica plastyczności, można uznać za dopuszczalne. $Z$ drugiej strony wielkość odkształceń limitować będzie zarys skrajni pudła, który zależy od konkretnego rozwiązania konstrukcyjnego wagonu.

Dalszą analizę wykonano dla rodziny porowatych powłok walcowych o grubości od $5 \mathrm{~mm}$ do $11 \mathrm{~mm}$. Z przeprowadzonych obliczeń wynika, że grubość powłoki ma niewielki wpływ na zachowanie konstrukcji wagonu przy działaniu obciążeń wzdłużnych w stosunku do konstrukcji klasycznej.

W przypadku obciążeń pionowych pochodzących od masy własnej i ładunku zauważono niewielkie zmniejszenie ugięcia ostoi wraz ze wzrostem grubości powłoki dachu. Odkształcenia przekroju poprzecznego pudła, a mianowicie zmiana wysokości (pionowej odległości dachu i ostoi) oraz zwiększenie szerokości pudła wzdłuż długości wagonu praktycznie pozostają na tym samym poziomie. Przedstawiono to graficznie na rys.2. Otrzymane wyniki są bardzo zbliżone do wartości jak dla konstrukcji klasycznej.

Odmienna sytuacja jest $\mathrm{w}$ przypadku obciążenia śniegiem. Przykładowy widok odkształceń konstrukcji pudła przedstawiono na rys.3. Ogólnie można stwierdzić, że powstałe w konstrukcji pudła odkształcenia powodują powstanie naprężeń znacznie niższych niż granica plastyczności, a więc nie ma obawy o pojawienie się odkształceń trwałych. Szczegółowe rezultaty przedstawiono w postaci graficznej na rys.4. Wynika z nich, że im grubsza powłoka walcowa tym mniejsza zmiana wysokości i mniejsze poszerzenie pudła. Najmniejsza zmiana wysokości pudła występuje w przekroju przechodzącym przez środek wagonu i jest prawie niezmienna $\mathrm{w}$ zależności od grubości. Spowodowane to jest faktem wprowadzenia w tym przekroju dwóch krokwi wraz ze ściągami.

Maksymalne poszerzenie pudła na wysokości pasa dachowego występuje w 1/4 długości wagonu i w zależności od grubości powłoki waha się $\mathrm{w}$ granicach od 9,4 do $17,4 \mathrm{~mm}$. Dla porównania maksymalne poszerzenie wagonu o konstrukcji klasycznej wynosi około $3,4 \mathrm{~mm}$. Należy się spodziewać, że prognozowane poszerzenie konstrukcji pudła $\mathrm{z}$ powłoką walcową może przysporzyć problemy z wpisywaniem się wagonu w zarys skrajni kolejowej. 

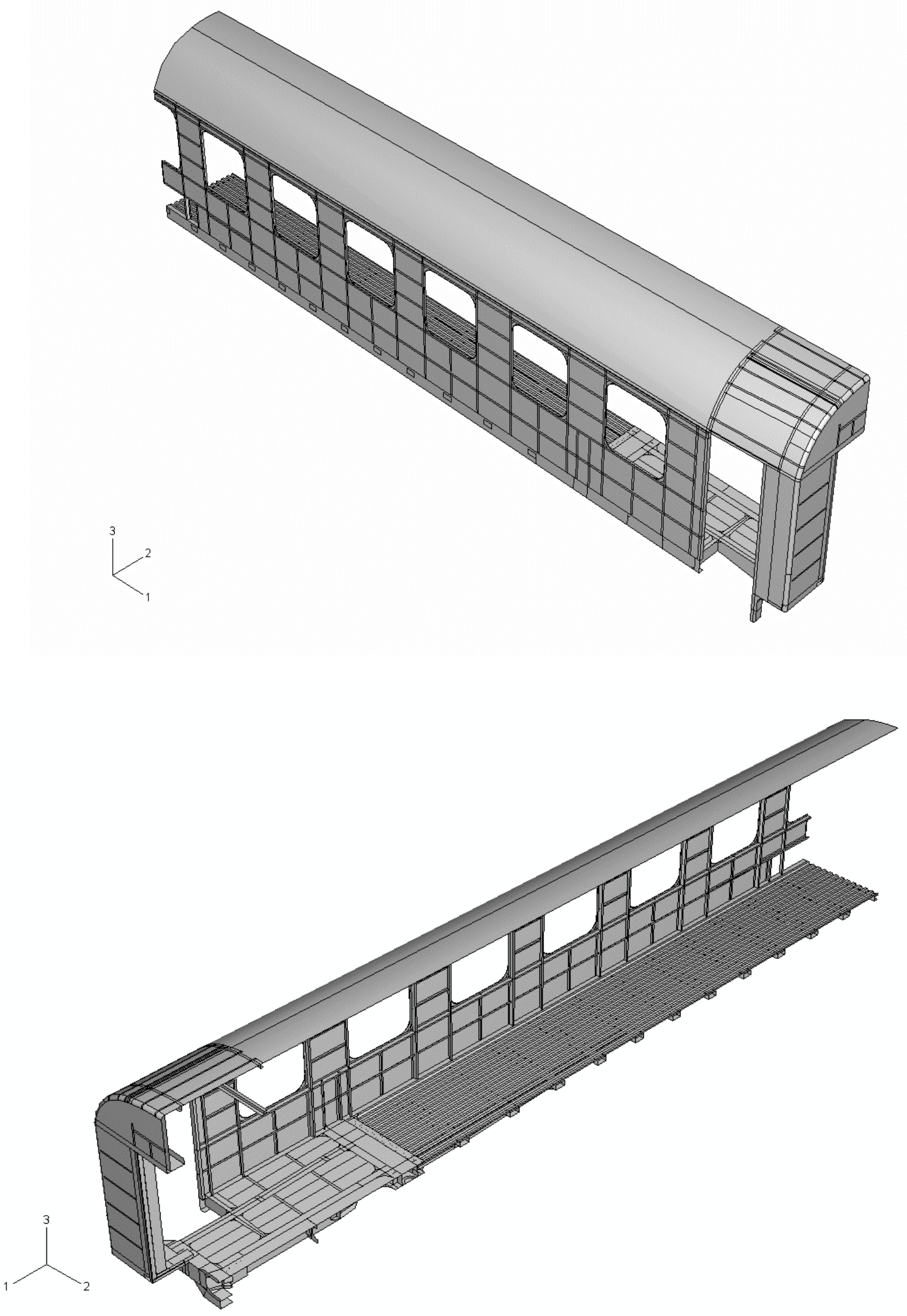

Rys.1. Model ćwiartki wagonu osobowego 


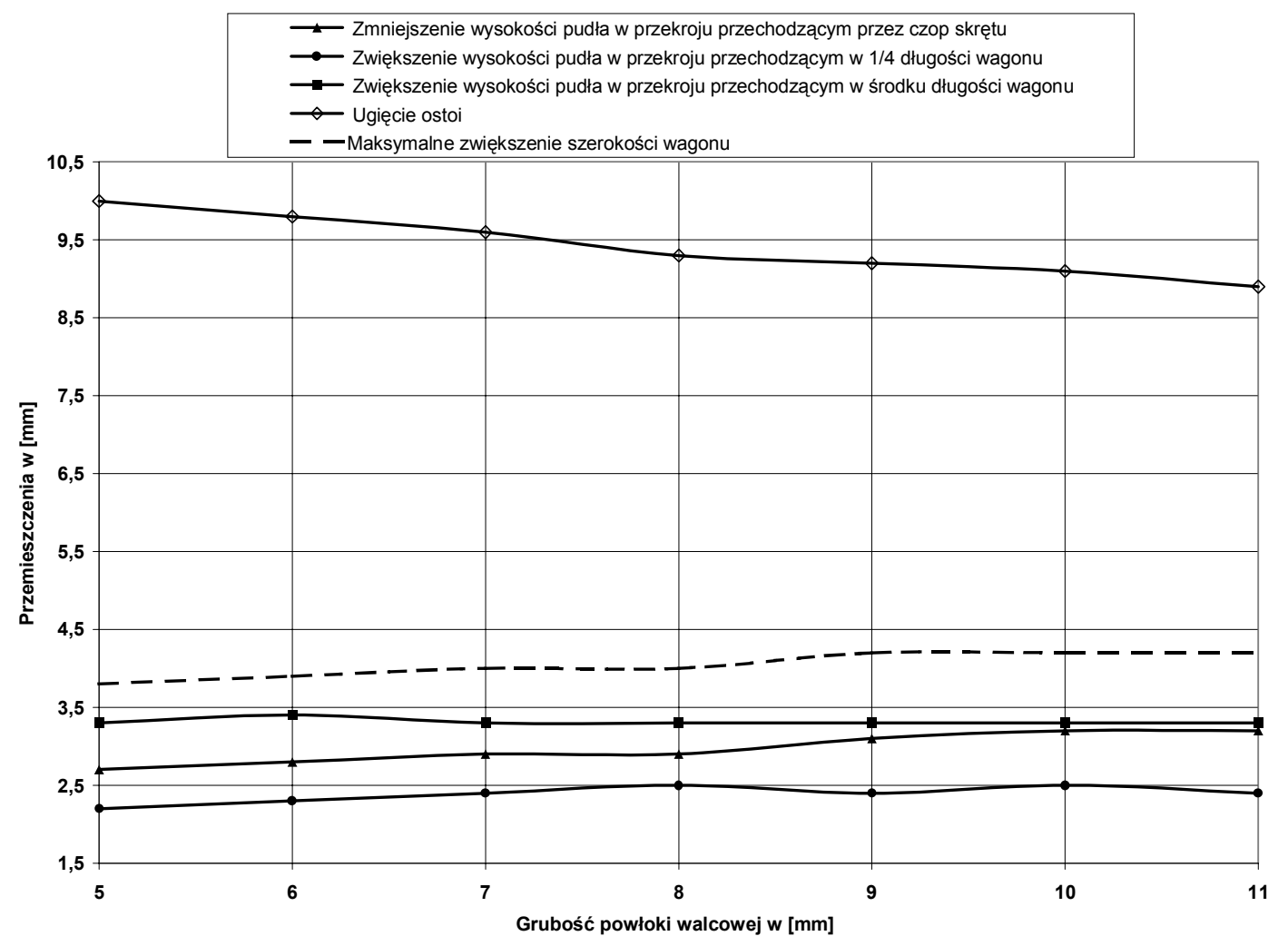

Rys.2 Zmiany wysokości i szerokości pudła w zależności od grubości powłoki w przypadku obciążeń pionowych
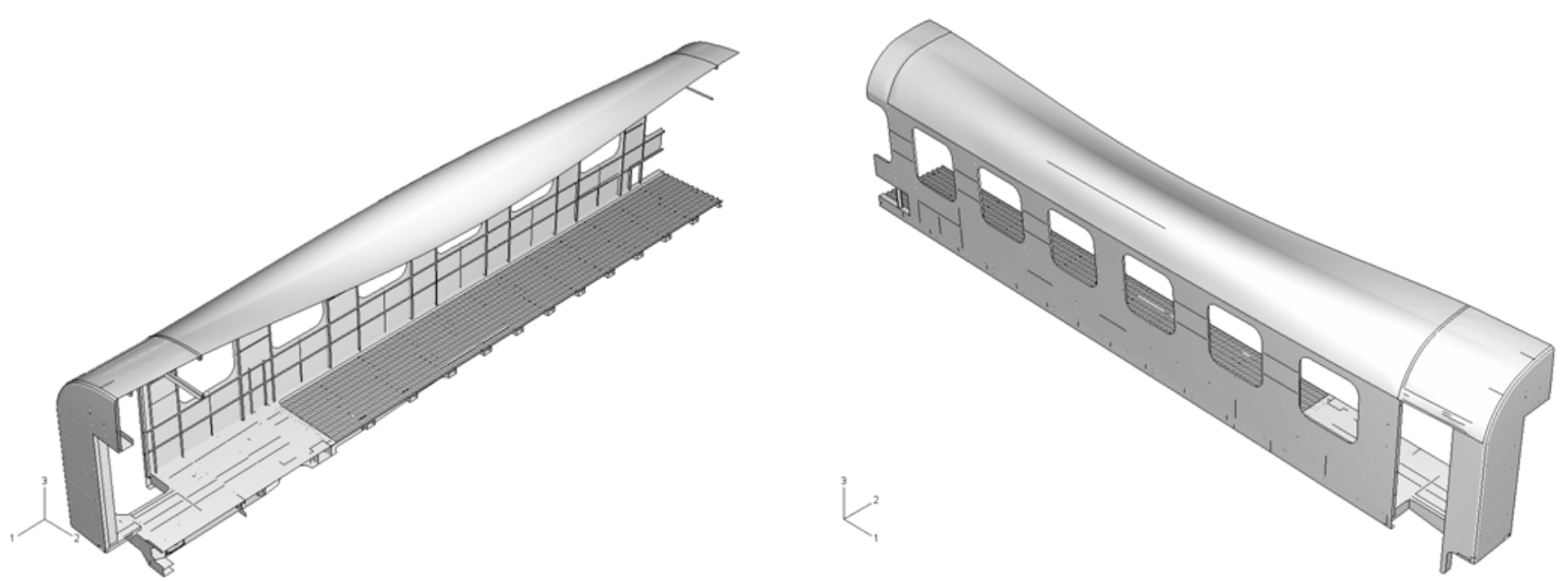

Rys.3 Odkształcenia konstrukcji wagonu z jednym zestawem krokwi na środku pod obciążeniem śniegiem

Wobec powyższego zaproponowano wprowadzenie dodatkowych dwóch par krokwi wraz ze ściagami w miejscu największego poszerzenia pudła. Zabieg ten umożliwił znaczne ograniczenie poszerzenia pudła wagonu pochodzące zwłaszcza od obciążenia śniegiem. Widok odkształconego pudła przedstawiono na rys.5. Maksymalne poszerzenie pudła zmienia się $\mathrm{w}$ zależności od grubości powłoki w granicach od 2,4 do $4,0 \mathrm{~mm}$, a więc jest prawie czterokrotnie mniejsze niż $\mathrm{w}$ poprzednio analizowanym rozwiązaniu. Również znacznie mniejsza jest zmiana wysokości pudła.
W rejonach podparcia na krokwiach utrzymuje się na bardzo niskim i stałym poziomie. Maksymalne wgniecenia pionowe powłoki walcowej występują między podparciami na krokwiach i w zależności od grubości powłoki zmieniają się od 3.1 do $5.8 \mathrm{~mm}$. Szczegółowe rezultaty przedstawiono w postaci graficznej na rys.6.

Zachowanie się konstrukcji dachu w przypadku obciążeń pionowych jest prawie identyczne jak w przypadku poprzednio analizowanego rozwiązania. 


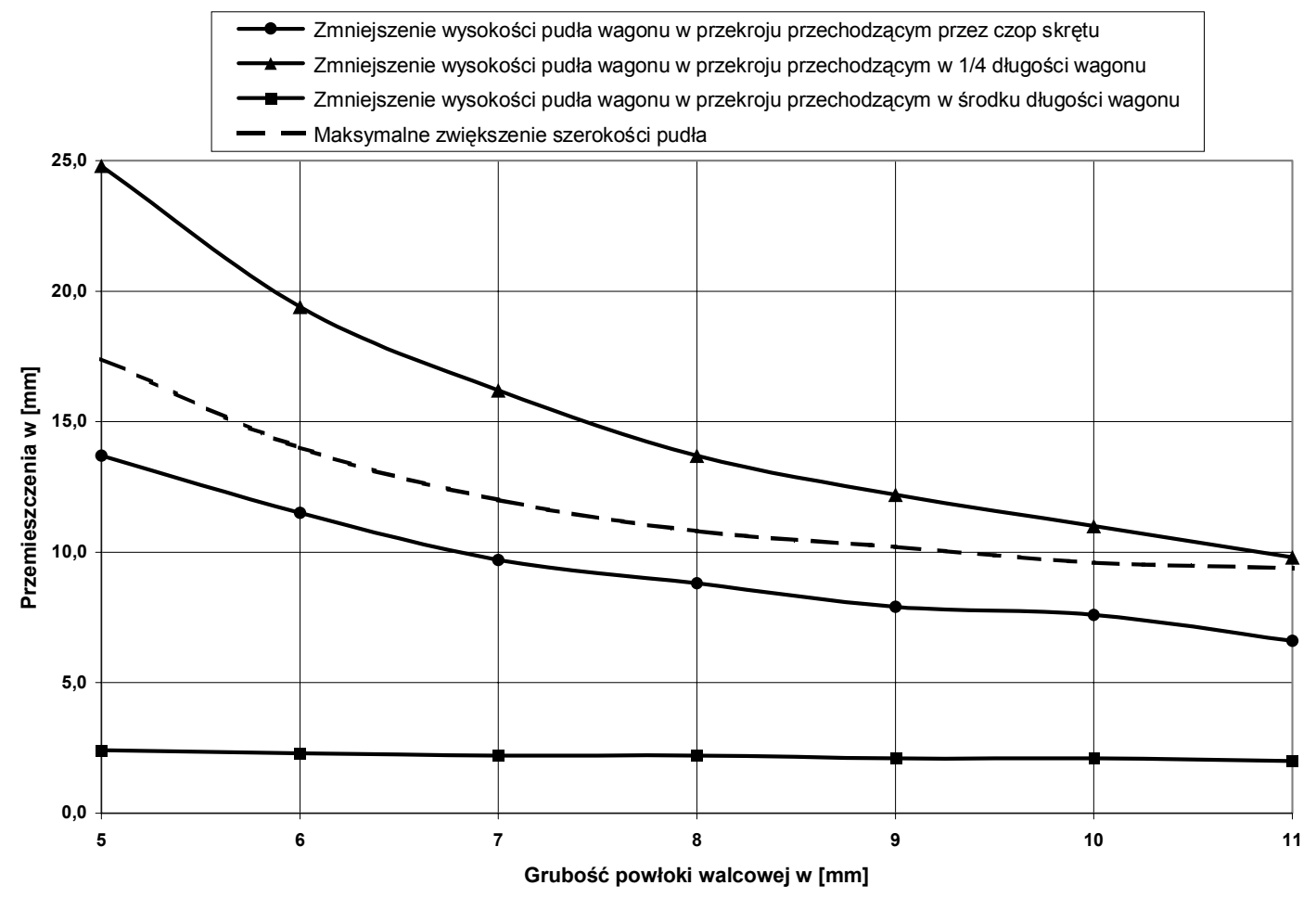

Rys.4. Zmiany wysokości i szerokości pudła w zależności od grubości powłoki w przypadku obciążenia śniegiem (konstrukcja dachu z jednym zestawem krokwi)
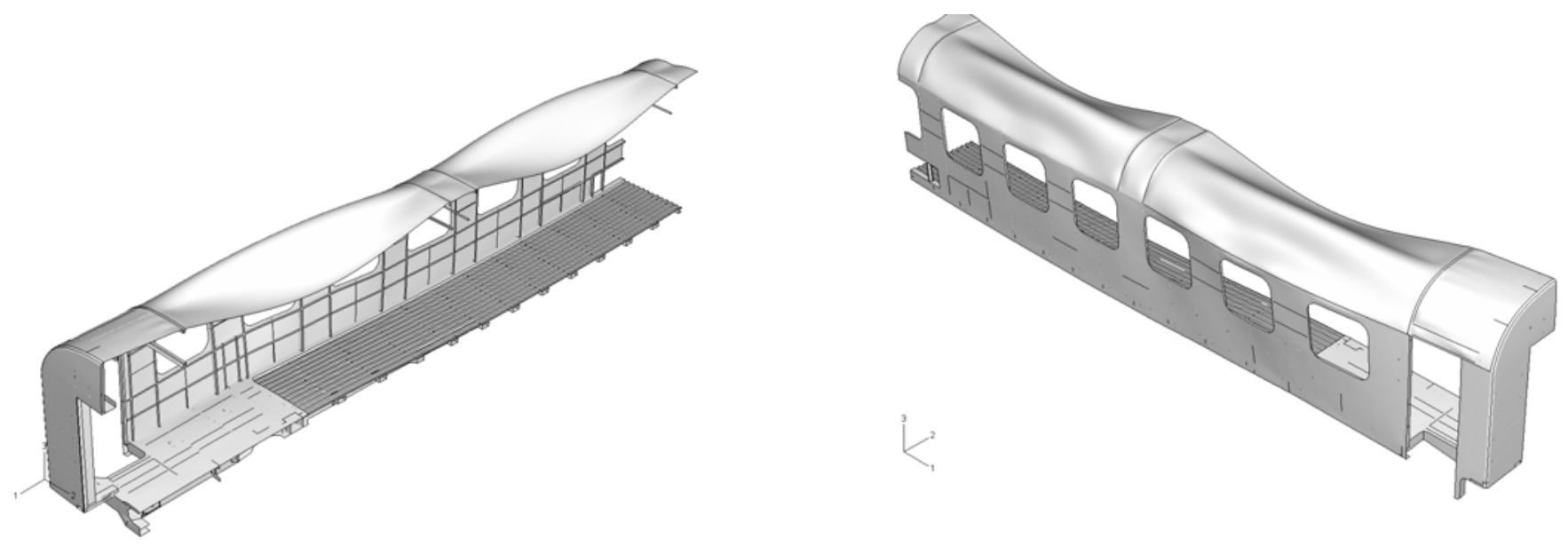

Rys.5 Odkształcenia konstrukcji wagonu z trzema zestawami krokwi pod obciążeniem śniegiem

Zmiany w konstrukcji nośnej dachu wagonu pasażerskiego polegające na zastapieniu dotychczasowej konstrukcji szkieletowej, powłoką o strukturze porowatej podpartej $\mathrm{w}$ newralgicznych miejscach za pomocą krokwi, przyczyniają się do możliwości obniżenia masy dachu.
W tabeli 1 zestawiono stosunki mas proponowanych rozwiązań konstrukcyjnych $\mathrm{m}_{\mathrm{PI}}$ (powłoka walcowa + jeden zestaw krokwi) oraz $\mathrm{m}_{\mathrm{PII}}$ (powłoka walcowa + trzy zestawy krokwi) do klasycznego $m_{K}$. 


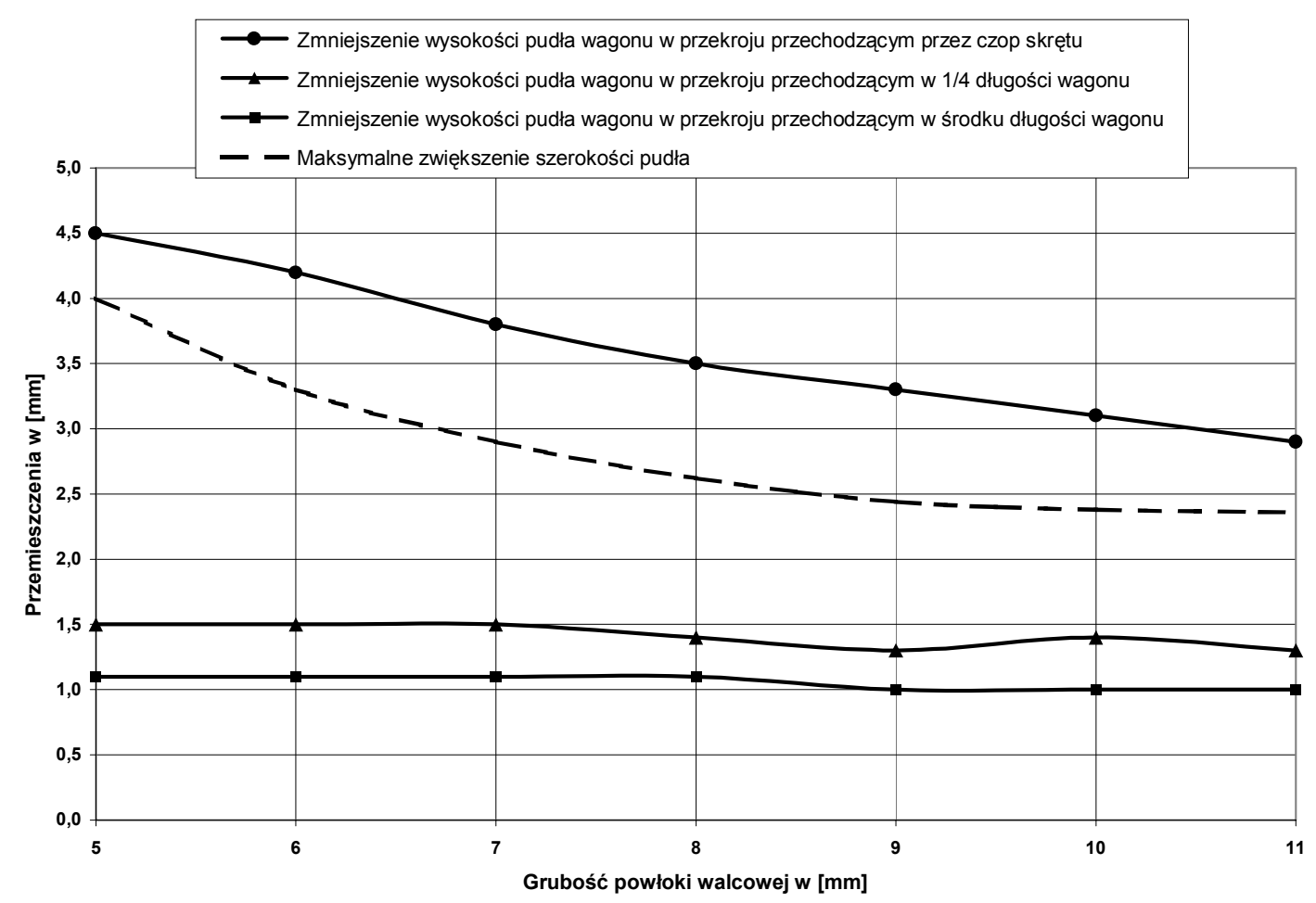

Rys.6. Zmiany wysokości i szerokości pudła w zależności od grubości powłoki w przypadku obciążenia śniegiem (konstrukcja dachu z trzema zestawami krokwi)

Zestawienie stosunków mas konstrukcji dachów z porowatą powłoką walcową $\mathrm{m}_{\mathrm{PI}} \mathbf{i} \mathrm{m}_{\mathrm{PII}}$ oraz klasyczną konstrukcją szkieletową $\mathbf{m}_{K}$

Tabela 1

\begin{tabular}{|c|c|c|}
\hline $\begin{array}{c}\text { Grubość po- } \\
\text { włoki porowa- } \\
\text { tej [mm] }\end{array}$ & $\mathrm{m}_{\mathrm{PI}} / \mathrm{m}_{\mathrm{K}}$ & $\mathrm{m}_{\mathrm{PII}} / \mathrm{m}_{\mathrm{K}}$ \\
\hline 5 & 0,42 & 0,47 \\
\hline 6 & 0,49 & 0,54 \\
\hline 7 & 0,57 & 0,62 \\
\hline 8 & 0,64 & 0,69 \\
\hline 9 & 0,72 & 0,77 \\
\hline 10 & 0,79 & 0,84 \\
\hline 11 & 0,87 & 0,92 \\
\hline
\end{tabular}

Przedstawione rezultaty analiz wytrzymałości dotyczą konstrukcji pudła wagonu osobowego $\mathrm{z}$ dachem wykonanym $\mathrm{z}$ powłoki o strukturze porowatej $\mathrm{o}$ współczynniku porowatości $\mathrm{e}_{0}=0,9$. Kolejnym etapem prac była ocena wpływu współczynnika porowatości na analizowane dotychczas wielkości. Przeprowadzono szereg analogicznych analiz, dla konstrukcji z trzema zestawami krokwi, dla różnych współczynników porowatości powłoki dachu: $\mathrm{e}_{0}=0,45 ; 0,60 ; 0,75$. Wynika z nich, że sztywność pionowa pudła wagonu $\mathrm{w}$ przekrojach przechodzacych w miejscach wprowadzenia dodatkowych zestawów krokwi, jest praktycznie niezależna od współczynnika porowatości. Spowodowane jest to oczywiście wystarczającą sztywnością pionową istniejącego szkieletu stalowego.
W niepodpartym rejonie dachu (np. mniej więcej nad czopem skrętu) sztywność pionowa pudła jest największa dla najmniejszego współczynnika porowatości $\left(\mathrm{e}_{0}=0,45\right)$. Najwyraźniej widać to dla dachu obciążonego śniegiem, co przedstawiono na rys.7 zestawiając rezultaty analiz dla $\mathrm{e}_{0}=0,45$ i $\mathrm{e}_{0}=0,9$. Zmiana wysokości pudła wagonu jest najmniejsza dla współczynnika porowatości $\mathrm{e}_{0}=0,45 . \mathrm{Z}$ wykresów wynika również, że sztywność poprzeczna decydująca o zmianie szerokości pudła wagonu jest także największa dla współczynnika porowatości $\mathrm{e}_{0}=0,45$. Zmiany wysokości pudła $\mathrm{w}$ miejscach wprowadzenia do konstrukcji zestawów krokwi utrzymują się na prawie stałym poziomie, a więc są niezależne od porowatości powłoki dachu.

W przypadku obciążenia pionowego, wzrost masy własnej porowatej powłoki dachu spowodowanej zmniejszeniem współczynnika porowatości, przyczynia się do tego, że mimo większej sztywności pionowej zmiany wysokości i szerokości pudła są większe. Oczywiście dotyczy to głównie niepodpartych rejonów pudła. W rejonach zestawów krokwi zmiany wysokości są niezmienne $\mathrm{w}$ zależności od porowatości.

Należy jednak pamiętać, że wraz ze zmniejszaniem się współczynnika porowatości powłoki rośnie jej masa i w związku z tym ograniczony jest swobodny wybór grubości powłoki. 


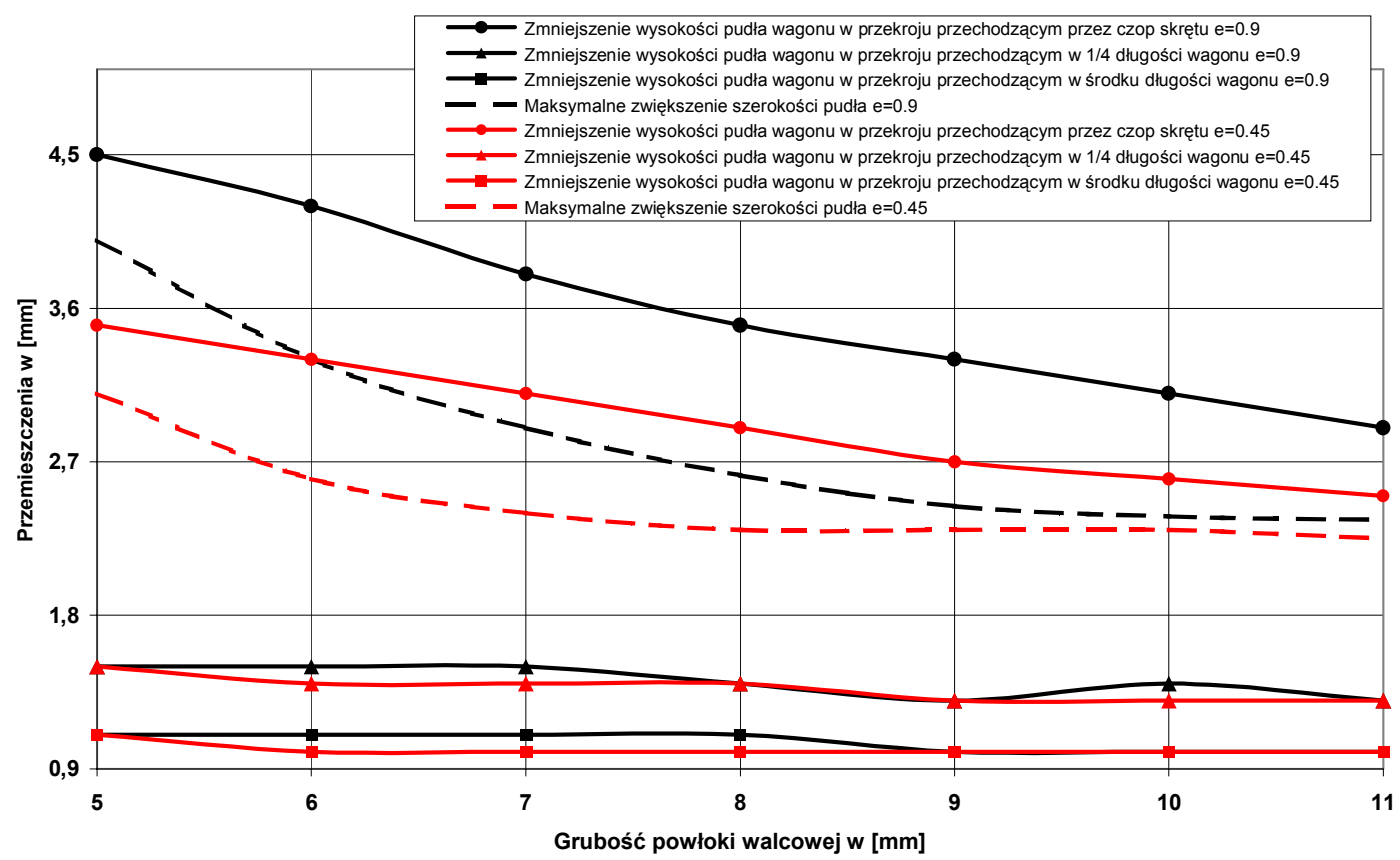

Rys.7. Zmiany wysokości i szerokości pudła w funkcji grubości powłoki w zależności od współczynnika porowatości dla przypadku obciążenia śniegiem (konstrukcja dachu z trzema zestawami krokwi)

\section{Wnioski}

Z przeprowadzonych analiz widać, że zastapienie dachu wagonu osobowego o konstrukcji szkieletowej porowatą powłoką walcową jest w pełni możliwe pod warunkiem zachowania fragmentu szkieletu dachu w postaci zestawów krokwi wraz ze ściagami.

Przedstawione propozycje rozwiązań konstrukcyjnych zapewniają spełnienie wymagań wytrzymałościowych wynikających $\mathrm{z}$ przepisów kolejowych. Natomiast $\mathrm{z}$ drugiej strony, pozostawienie fragmentu szkieletu dachu umożliwia zrealizowanie zamierzeń projektowych w zakresie mocowania urządzeń niezbędnych do prawidłowego funkcjonowania wagonu.

Podstawową zaletą proponowanego rozwiązania jest znaczne obniżenie masy konstrukcji nośnej. Z przeprowadzonych wyliczeń wynika, że w zależności od grubości oraz porowatości powłoki masa dachu może stanowić około $47 \%$ masy dotychczasowej konstrukcji klasycznej.

Ponadto elementy konstrukcyjne wykonane $\mathrm{z}$ materiałów o strukturze porowatej posiadają bardzo dobre własności izolacji cieplnej oraz thumienia hałasu. Powoduje to, że zastosowanie ich umożliwi uniknięcie lub znaczne ograniczenie dodatkowego ocieplania i wygłuszania konstrukcji. Odpowiedni dobór materiałów użytych do budowy takich konstrukcji powoduje możliwość uzyskania wymaganej ognioodporności. Wymienione powyżej zalety $\mathrm{z}$ całą pewnością prowadzą do znacznego obniżenia kosztów wytworzenia i eksploatacji konstrukcji.
Reasumując można stwierdzić, że rozważania na temat zastosowania elementów powierzchniowych o strukturze porowatej $\mathrm{w}$ budowie pojazdów szynowych sa jak najbardziej zasadne. Pozytywne rezultaty zmian konstrukcyjnych $\mathrm{w}$ dachu powinny stanowić przyczynek do zastanowienia się nad zastosowaniem elementów powierzchniowych o strukturze porowatej w innych rejonach konstrukcji nośnej wagonu jak na przykład ściany boczne.

\section{Literatura}

[1] Mielniczuk J., Malinowski M.: Modele materiatów porowatych $w$ projektowaniu konstrukcyjnych elementów powierzchniowych, Pojazdy Szynowe, $\mathrm{Nr} 3 / 2005$.

[2] Mielniczuk J., Malinowski M., Kuligowski P.: Elementy powierzchniowe o strukturze porowatej w konstrukcji dachów pojazdów szynowych, Pojazdy Szynowe, Nr 2/2006.

[3] Mielniczuk J., Kuligowski P.: Konstrukcja dachu wagonu pasażerskiego z zastosowaniem materiatu o strukturze porowatej, Pojazdy Szynowe, Nr $3 / 2007$. 